using digital geographic data, the volume of which is constantly increasing, and types, formats and sources of income are diversified.

\title{
References:
}

1. Korchenko O., Pohrebennyk V., Gancarczyk J., Sheviakina N., Zagorodnia S. Use of modern information technologies for and management of nature reserve areas/ International multidisciplinary scientific geoconference SGEM 2019. Albena, Bulgaria. 2019. P. 697-703.

2. Trofymchuk O., Yakovliev Y., Klymenko V., Anpilova Y. Geomodeling and monitoring of pollution of waters and soils by the earth remote sensing. International Multidisciplinary Scientific GeoConference SGEM. 2019. № 1-4. Pp 197-204.

3. Lukianova, V., Trofymchuk, O., Anpilova, Y. Environmental safety of motor transport enterprises within the urban areas. Journal of Ecological Engineering. 2020. Vol. 21(4). Pp 231-236.

4. Trofymchuk O., Zahorodnya S., Sheviakina N., Radchuk I., Tomchenko O. Remote Sensing Monitoring of Biotopes Distribution within Nature Reserve Area. Journal of Environmental Research, Engineering and Management. 2020. Vol. 76. No. 3. Pp. 109-120.

DOI https://doi.org/10.30525/978-9934-26-046-9-5

\section{ОБГРУНТУВАННЯ НАПРЯМКІВ \\ ЗАСТОСУВАННЯ ТЕХНОЛОГІЙ ШТУЧНОГО ІНТЕЛЕКТУ У ВІЙСЬКОВІЙ КІБЕРНЕТИЦІ}

\author{
Івахненко Т. 0. \\ кандидат технічних наук, \\ провідний науковий співробітник науково-дослідного відділу \\ Центральний науково-дослідний інститут озброєння \\ та військової техніки Збройних Сил Украӥни \\ м. Київ, Украӥна
}

Вступ. Зразки озброєння та військової техніки (ОВТ), побудовані відповідно до традиційних принципів дії та фізичної (поелементної) побудови, невпинно приближуються до своїх граничних можливостей, що зумовлює необхідність пошуку та застосування нетрадиційних підходів при подальшому розвитку ОВТ та інших прин- 
ципів побудови і використання засобів протиборства та збройної боротьби [1-3].

Головна архітектурна особливість, яка відрізняє інтелектуальну систему від системи, побудованої за традиційною схемою, пов'язана iз впровадженням механізмів зберігання та обробки знань для реалізації здібності з виконання покладених на неї функцій, у невизначених умовах та при випадковому характері зовнішнього впливу.

До них можливо віднести непередбачувану зміну цілі, експлуатаційних характеристик системи та об’єкта управління, параметрів зовнішнього середовища та ін. Таким чином, визначення основних напрямків використання технологій із застосуванням методів та технологій штучного інтелекту в оборонній сфері має актуальний характер.

Виклад основного матеріалу дослідження. Штучний інтелект $\epsilon$ одним із нових напрямків розвитку прикладної науки. Властивості цього напрямку можливо визначити як напрям діяльності, що проявляється в здібності за допомогою інформаційних (не обов'язково комп'ютерних, а в майбутньому можливо біоінформаційних) систем застосовувати практичні додатки раціональних рішень у наперед необмеженому числі різноманітних ситуацій, в тому числі (можливо перед усім) в умовах невизначеності (слабкої структурованості інформації).

Штучний інтелект вже в найближчий час забезпечить приріст ефективності діяльності в таких областях військової справи як:

моделювання, ведення бойових дій та обгрунтування складу сил та засобів, що застосовуються;

функціонування інтегрованих систем розвідки та управління, дистанційно-керованих, розвідувально-ударних бойових комплексів, робототехнічних систем військового призначення та ін.;

управління мобільними розподіленими системами бойової охорони заданих кордонів та об'єктів;

використання тренажерів, навчаючих систем та ін.

Іншим напрямком використання штучного інтелекту в військовій справі можуть бути системи ОВТ, такі як:

комп’ютерні системи, що здатні до самонавчання, придатні до обробки не структурованої інформації за сучасними та перспективними матеріалами, електронно-елементної бази, промисловими технологіями, окремими деталями, вузлами та агрегатами, здійснення їх поєднання та сполучення (енергетичного, матеріального, інформаційного та ін.) в зразках ОВТ; високопродуктивні обчислювальні інтелектуальні системи для пришвидшеної розробки зразків ОВТ із 
врахуванням інформації про можливості застосування нових, невідомих раніше засобів атаки противника в загрозливий період; інтелектуальні програмно-технічні комплекси створення засобів захисту, адаптації до нестабільних параметрів обстановки, що змінюють властивості під впливом вражаючих факторів сучасної зброї та інш.

Особливу значимість у військовій справі набудуть системи прийняття рішень по відсічі нападу противника - системи аналізу факту та способу нападу противника, яка спроможна до самонавчання, оцінки складу та характеристик зброї, що застосовується, параметрів точок ураження, втрати сил та засобів, визначення способу ефективної протидії.

Не менш важливими будуть інтелектуальні технології оперативного аналізу факторів ураження термічного, баричного, біохімічного та іншого характеру, пришвидшене виготовлення ліків та препаратів 3 врахуванням характеру ушкоджень та стану потерпілого, конструювання антидотів та білків, нейтралізуючих джерела ураження токсичними речовинами та новими патогенними мікроорганізмами.

Важливим аспектом також є удосконалення методів оцінки фізичного, психофізіологічного та психічного стану військовослужбовців при проведенні бойових дій, уточнення їм задач та корекції дій із врахуванням їх стану.

Наступний напрямок пов'язаний із вдосконаленням ергономічних характеристик ОВТ шляхом створення біокібернетичних кабін операторів 3 повною інтеграцією системи життєзабезпечення військовослужбовців, із засобами інтелектуальної та психофізіологічної підтримки, адаптивних та здатних до перебудови у відповідності із вирішуваними бойовими задачами, індивідуальними характеристиками операторів та їх фізичним станом на даний момент.

На цей час активно продовжуються дослідження і в області створення інтелектуальних тренажерів для навчання операторів, водіїв, льотчиків основним правилам керування ОВТ в складній обстановці, імітації бойових дій, оцінки психофізичного стану осіб, що навчаються, їх можливостей дій в аварійних та інших ситуаціях.

Особливу роль в найближчому майбутньому будуть відігравати інтелектуальні технології розвідки, засновані на методах «розумного» компонування, прив'язки, дешифрування матеріалів розвідки, інтелектуальної обробки інформації, що отримана від органів розвідки, в тому числі кібер-розвідки, підготовки рекомендацій, розвідувальноінформаційного забезпечення застосування зброї.

Стосовно штучного інтелекту в цілому, можливими причинами виникнення ризиків буде наступне: недоліки та обмеженість методів 
штучного інтелекту, що пов'язані, наприклад, 3 неповним обліком етичних норм; недостатній розвиток теорії співпраці когнітивних систем, що призводить до неадекватної комунікації в системі «людина-штучний інтелект», проблеми штучного інтелекту військового призначення.

При розгляді граничних можливостей штучного інтелекту виникає питання про те, чи зможуть дані методи (наприклад, нейронні мережі) «змоделювати» рішення командира на полі бою.

На сьогодні технології штучного інтелекту дозволяють підвищити бойову ефективність зразків ОВТ, зменшити витрати на їх експлуатацію, зменшити ризик поранень та загибелі людей. В цілому розвиток науково-технічного прогресу буде сприяти все більшому застосуванню штучного інтелекту у військовій справі.

Висновки. Інноваційний розвиток збройних сил держави обумовлює необхідність планомірної інтеграції в їх систему озброєння, поряд iз традиційними видами ОВТ, принципово нових нетрадиційних зразків, в тому числі і тих, котрі містять засоби, що використовують вбудовані елементи штучного інтелекту. Хоча це і потребує суттєвих фінансових затрат та інших ресурсів, проте, дотримуючись тенденцій розвитку збройних сил провідних країн світу, необхідно послідовно переходити на впровадження подібних інновацій, котрі передбачають використання наведених сучасних засобів.

Це, в свою чергу, потребує подальшого розвитку науковотехнічної, проектно-конструкторської та виробничо-технологічної бази обороннопромислового комплексу. Без неї стає неможливим створення наукомістких та високотехнологічних зразків ОВТ для потреб збройних сил країни.

Стосовно основних напрямків застосування технологій, що містять елементи та методи штучного інтелекту в оборонній сфері, то такими слід вважати наступні: моделювання, ведення бойових дій та обгрунтування складу сил та засобів, що застосовуються в них; організації функціонування інтегрованих систем розвідки та управління, дистанційно-керованих, розвідувально-ударних бойових комплексів, різних робото-технічних систем військового призначення та інш.

Даний матеріал, з практичної точки зору, буде доцільним використовувати при визначенні заходів щодо визначення шляхів вдосконалення системи ОВТ як на середньострокову, так і довгострокову перспективу їх розвитку, особливо в частині подальшого розвитку систем управління, силами та засобами збройної боротьби. 


\title{
Література:
}

1. Величко О. Ф., Гриб Д. А., Демідов Б. О., Луханін М. І. Проблемні аспекти інтеграції нетрадиційних видів озброєння до складу перспективної системи озброєння збройних сил держави. Озброєння та військова техніка. 2017. № 3(15). С. 77-83.

2. Cummings M.L. Research Paper Artificial Intelligence and the Future of Warfare [Electronic resource]. International Security Department and US and the Americas Programme, London 2017. 18 p. Режим доступу: https://www.chathamhouse.org/publication/artificial-intelligenceand-future-warfare (дата звернення 25.01.2021).

3. UK Essays. Artificial Intelligence In Military Application Information Technology Essay. November 2013. [Electronic resource]. Режим доступу: https://www.ukessays.com/essays/informationtechnology/artificial-intelligence-in-militaryapplication-informationtechnology-essay.php?vref=1 (дата звернення 25.01.2021).

DOI https://doi.org/10.30525/978-9934-26-046-9-6

\section{ORGANIZATION OF DISTANCE LEARNING SYSTEM AT KHARKIV MEDICAL UNIVERSITY IN AN EMERGENCY SITUATION}

\begin{abstract}
Kocharova T. R.
Senior Lecturer at the Department of Medical and Biological Physics and Medical Informatics

Kharkiv National Medical University

Popov M. Yu.

Student at the III Medical Faculty

Kharkiv National Medical University

Kharkiv, Ukraine

This problem has been relevant in nowadays quarantine measures. In addition, we can evaluate objectively on the example of our university, highlighting the benefits. The history of distance learning began in the 18th century with the development of postal communication between cities in the form of «correspondence».
\end{abstract}

